\title{
Determination of Work Index of Enyigba Lead Ore, Ebonyi State, South-East Nigeria
}

\author{
Obassi Ettu ${ }^{1}$, Gundu D.T. ${ }^{2}$, Ashwe Abugh ${ }^{3}$, Akindele. M. ${ }^{4}$ \\ ${ }^{1}$ Raw Materials Research and Development Council, Abuja, Nigeria \\ ${ }^{2,3}$ Department of Mechanical Engineering, University of Agriculture, Makurdi \\ ${ }^{4}$ Department of Mineral Resources Engineering, Kaduna Polytechnic, Kaduna \\ Correspondence: Obassi Ettu, Raw Materials Research and Development Council, Abuja, Nigeria
}

Received: May 19, 2015 Accepted: June 8, 2015 Online Published: July 29, 2015

doi:10.11114/set.v2i1.987 URL: http://dx.doi.org/10.11114/set.v2i1.987

\begin{abstract}
The determination of work index of Enyigba Lead Ore, Ebony State using the modified bond energy (Berry \& Bruce) method was investigated. The test sample was obtained from Enyigba village in Ebonyi State. A reference material (granite) was sourced from Anguwan-Boro granite deposit, Sabo, Kaduna metropolis. A known weight of reference and test material were crushed, pulverized and ground using the laboratory ball mill machine. The cell used in grinding the two samples has twelve steel balls of diameter $3.5 \mathrm{~cm}$ and $222 \mathrm{~g}$ weight. The size analysis of the feed for both reference and test material was found to be 218.2 and $218.6 \mu \mathrm{m}$, and a ball mill discharge was 189.9 and $188.9 \mu \mathrm{m}$ respectively. The granite as a reference material with work index of $15.13 \mathrm{kwh} / \mathrm{short}$ ton was used to calculate the work index of the test material which was found to be $14.37 \mathrm{kwh} /$ short ton, being the energy required to comminute one tone of the ore and confirmed to be within the range indicated by previous research work on lead ore.
\end{abstract}

Keywords: Bond's index, Enyigba Lead Ore, modified, reference mineral, mineral processing

\section{Introduction}

Nigeria is endowed with several mineral resources which are widely distributed across the country. Before the discovery of crude oil in the early 70s, Nigeria was once reckoned as a major mineral producer, accounting for substantial production of Casseterite (tin), Gold, Coal, Lead/Zinc Sulphides, Tantalite and Columbite. Few of these mineral deposit have been fully explored and their quantum ascertained, while further investigation is still required to determine the quantum of the occurrence of many other, which are not yet listed The Geology of Nigeria is comparable to those of other countries where world class deposits have been found. There are over thirty-four mineral commodities spread across the entire country. Some of the known mineral resources include: Gold, Coal, Bitumen, Iron Ore, Tantalite/Columbite, Lead/Zinc Sulphides, Barytes, Casseterite, Gemstones, Talc, Feldspar, Marble, etc.

In a world with limited energy resources, the need to design the energy requirements of engineering processes cannot be overemphasized. In the mineral industry, comminution is the highest consumer of energy. Napier-Munn et al. (1996) stated that $30-50$ per cent of the total plant power consumption for mineral processing plants and up to 70 per cent for hard ores is attributed to comminution. Whittles et al. (2003) observed that about 1.5 per cent of the annual electrical energy production in the United States of America is used in comminution processes in the minerals industry. Grindability is the ease with which materials can be comminuted and the data obtained from grindability tests are used to evaluate energy requirements and grinding efficiency.

The energy required to grind one tonne of an ore from a given feed size to a specified product size is a material property that needs to be determined for different ore deposits. The Bond's work index has generally been accepted as a measure of the grindability of an ore. This study used quartz as a reference ore via a comparative method to determine the Bond's work index of (Enyigba Nigeria) ore. The same amount of energy was utilized in grinding the reference and test ore with the same particle size distribution under the same grinding conditions. Typical feed load and mill speed in practice were used in order to make the grinding environment as close as possible to that in large scale grinding. The Bond's work index of Enyigba (Nigeria) ore was found to be $14.37 \mathrm{kwh} / \mathrm{short}$ ton. 


\section{Brief Geology of Lead/Zinc Occurrence/ Mineralization in Nigeria}

The Benue Trough is a major geological feature that houses the lead/zinc mineralization in Nigeria. Lead and zinc ores are usually found together in association with other minerals. They occur in commercial quantities in the Benue Trough, in a narrow belt over $560 \mathrm{~km}$ stretching from Ishiagu in the South-east to Bauchi State. Small-scale mining has been carried out in Enyigba in the Abakaliki area, where reserves of about 100,000 tonnes of lead and 80,000 tonnes of zinc have been estimated. Other major lead-zinc occurrences are at Ameka, Ameri in Ebonyi State, Arufu and Zurak in Taraba State. However, lead-zinc mining in Nigeria has been rather intermittent.

The Benue Trough is a NE-SW elongated Trough of subsidence which extends from the Gulf of Guinea to Lake Chad. It is considered as a part of the Pan African Mobile Zone of West Africa. The trough is divided into three (the lower, the middle and the upper Benue Trough) and is the $\mathrm{Pb}-\mathrm{Zn}$ mineral bearing feature in the Nigeria geology. See map below.

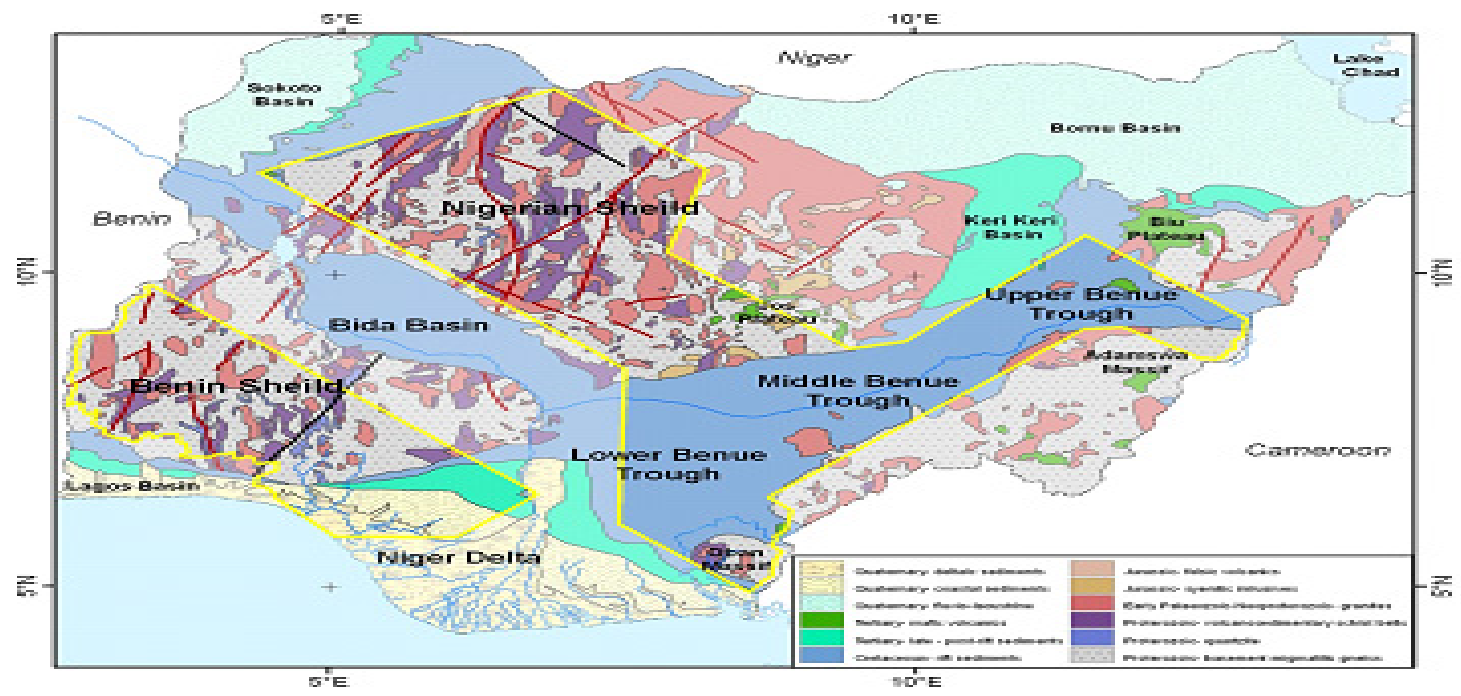

Fig. 1. Map showing the Lower-, Middle- and Upper Benue Trough

The lower Benue Trough houses the Ebonyi State $\mathrm{Pb}-\mathrm{Zn}$ mineralization emplaced at a low temperature of about $140^{\circ} \mathrm{C}$ and it is made up of primarily four lodes namely Ishiagu, Enyigba, Ameri and Ameka all in the present day Ebonyi state. In the Middle Benue Trough, veins are located mainly in Akwana and Arufu in Nassarawa state, while the Upper Benue Trough composed of the Zurak, Isimiya, Digi, Biu locations, etc) in Taraba and Borno States.

Previous works (Maurin, 1986; Maurin and Lancelot, 1987) have confirmed the hydrothermal origin at low temperature $\left(\sim-140^{\circ} \mathrm{C}\right)$ and proposed detrital feldspars as source rocks. A geophysical investigation (Etim et al., 1988) in part of the Lower Benue Trough has revealed, below the Albian shales of the Asu River Group the existence of sandstones interpreted as a possible source for the Abakallki mineralization. Mineralized ores are widely distributed in the Benue Trough and their structural characteristics indicate a tight control by the tectonics which has originated the Benue Trough. All the data relative to the mineralization are integrated in a genetic model based upon the structural and tectonic framework proposed for the Benue Trough (Benkhelfl, 1982).

The occurrence of lead-zinc mineralization in the Cretaceous series of the Benue Trough was firstly described about 40 years ago (Mackay, 1946). The origin of this mineralization has been variously interpreted but more generally related to magmatic intrusions (Farrington, 1952; Nwachukwu, 1974). A pure sedimentary origin was proposed (Grant, 1971; Olade, 1976; Olade and Morton, 1985) involving a circulation of connate-brines within the Cretaceous sediments. A third hypothesis (Offodile and Reyment, 1976) implies the combined effects of Juvenile and connate brines.

The lead-zinc ores occur discontinuously in a $500 \mathrm{~km}$ long belt stretching from the Southwestern end of the Abakaliki Anticlinorium to the Upper Benue region (Fig. 1). The lithostratigraphic environment of the mineralization is variable from the Albian shales of the Asu River Group in the Lower Benue to the Cenomanian siltstones and shales of the Yolde Formation in the Upper Benue. In the Middle Benue, the $\mathrm{Pb} / \mathrm{Zn}$ mineralization occurs as traces in long veins of baryte, calcite and quartz cutting across sandstones and shales of the Cenomanian Keana Sandstones.

The source of the mineralization is controversial as exposed in the introduction (Maurin and Benkhelil, 1990). A recent work on the $\mathrm{Pb}$ isotopic composition of the mineralization (Maurin, 1986; Maurin and Lancelot, 1987) has shown that the source of the lead is the Precambrian or the Albian/Cenomanian sediments, hypothesis previously proposed by Grant (1971) and Olade (1976). The low radiogenic character of the lead for a Cretaceous age indicates a source depleted in uranium which cannot be the magmatic bodies richer than the mineralization (Maurin and Lancelot, 1987). Most authors are in agreement with the epigenetic character of the hydrothermal mineralization with low temperature (- 
$140^{\circ} \mathrm{C}$ ) of formation (Nwachukwu, 1974; Olade and Morton, 1985).

The mineralization is mainly sphalerite and galena with accessory minerals such as chalcopyrlte, enargite, marcassite and tetraedrite (MacKay, 1946; Farrington, 1952). The gangue Model of $\mathrm{Pb} / \mathrm{Zn}$ mineralization genesis in may contain calcite, fluorite and baryte in the limestone, quartz in the sandstone, manganesiferous siderite, quartz and calcite in the shales.

Lead occurs naturally in the earth's crust at a concentration of approximately $8-20 \mathrm{mg} / \mathrm{kg}$ (Rudnick and Fountain, 1995; Taylor and McLennan, 1995). Concentrations of $\mathrm{Pb}$ are found in the crust hosted in either SEDEX (sedimentary exhalative), VMS (volcanogenic massive sulfide) or MVT (Mississippi valley-type) deposits and to a lesser extent veins and skarns (Lydon, 2007). These deposits are the most important resources of Pb globally. SEDEX deposits are the primary global producer and average a grade of $3.28 \mathrm{wt} . \% \mathrm{~Pb}$, but metal grades are highly variable. In SEDEX deposits, the bulk of the ore is contained in stratiform sulfide bodies that are commonly represented by sheets or tabular lenses of stratiform sulfides up to a few tens of meters in thickness and more than a kilometer in length (Large, 1983; Goodfellow and Lydon, 2007). Most SEDEX deposits are hosted in basal marine, reduced facies, fine-grained sedimentary rocks consisting of mostly carbonaceous sandstones and dark shales.

Lead is a relatively soft, malleable, blue-grey, heavy metal and is probably the earliest discovered metal that does not occur naturally in pure state (Anon, 2014).

Lead is one of the most widely used metals and over $70 \%$ of all lead produced is used in lead-acid batteries for the storage of energy. Other uses include lead foil, plumbing, solder, sound proofing, ammunition, addition to glass to block harmful radiation from television and computer screens and as an ultraviolet ray protector in PVC plastics. Lead is toxic in some applications and environmental and health concerns have reduced its use in paint pigments and anti-knock additives in petrol. Over $50 \%$ of the supply is recycled from scrap, particularly lead-acid batteries of which $>90 \%$ are recycled. Table 1: shows the consumption pattern of lead and zinc.

Table 1.Industrial Consumption Pattern of Lead and Zinc Minerals

\begin{tabular}{|c|c|c|c|c|}
\hline $\begin{array}{l}\text { LEAD }(\mathrm{Pb}) \\
\text { Industry }\end{array}$ & & $\begin{array}{l}\text { WorldPercentage } \\
\text { Consumption }(\%)\end{array}$ & $\begin{array}{l}\text { ZINC (Zn) } \\
\text { Industry }\end{array}$ & $\begin{array}{l}\text { WorldPercentage } \\
\text { Consumption (\%) }\end{array}$ \\
\hline Batteries & & 71 & Galvanizing & 47 \\
\hline $\begin{array}{l}\text { Pigments and } \\
\text { Compounds }\end{array}$ & other & 12 & Brass and Bronze & 19 \\
\hline $\begin{array}{l}\text { Rolled and } \\
\text { Products }\end{array}$ & Extruded & 7 & Zinc Alloying & 14 \\
\hline Shots/Ammunition & & 6 & Chemicals & 9 \\
\hline Cable sheathing & & 3 & Semi-Manufacturing & 8 \\
\hline Alloys & & 1 & Miscellaneous & 3 \\
\hline TOTAL & & 100 & & 100 \\
\hline
\end{tabular}

Source: www.ime.co.uk/zinc-industryusage.asp

Comminution is a process in which solid material are reduced in size, this take place in mineral processing plant as a sequence of crushing and grinding process. Crushing reduces the particle size of run-off-mine ore to such a level that grinding can be carried out until the mineral and gangues are substantially produced as separated particles (Wills, 2006).

Determination of the required amount of energy to effect rock-breakage is of fundamental important in process design and which is achieved through work index determination. Work index is the comminuting parameter which expresses the resistance of the material to crushing and grinding, numerically; it is the kilowatt hour per short ton required to reduce the material from theoretically infinite size to $80 \%$ passing 100 micron, (Magdalimovic, 1989).

The determination of work index using modified Bond's method can be compared to the method used by Berry and Bruce (1966). This method requires the use of a reference ore of known grindability.

The objective of this study is to determine the energy consumed in comminuting Enyigba Lead Ore using the modified Bond's method.

\section{Theoretical Consideration for Comminution Process (Work Index)}

There are many theories of comminution, but paramount importance to this work is the modified Bond's equation called Berry and Bruce comparative Bond's equation that was used to determine the work index of the ore.

Work index is the comminution parameter which expresses the resistance of material to crushing and grinding; it is the kilowatt hour per short-ton required to reduce the material from theoretically infinite feed size to $80 \%$ passing $100 \mu \mathrm{m}$ (Wills and Napier-Mum, 2006). 
Table 1gives the work index of some minerals ores samples.

\begin{tabular}{cccc}
\hline Material & Work index & Material & Work index \\
\hline Barite & $4.28-6.24$ & Fluorspar & $2.98-9.76$ \\
Bauxite & $2.38-9.45$ & Granite & $2.68-15.13$ \\
Coal & $1.63-11.37$ & Graphite & $1.75-45.03$ \\
Dolomite & $2.82-11.27$ & Limestone & $2.69-11.61$ \\
Emery & $3.48-58.18$ & Quartzite & $2.71-12.18$ \\
Columbite & $3.94-10.81$ & Titanium ore & $4.23-11.88$ \\
Tantalite & $3.6-11.90$ & Silica sand & $2.65-16.46$ \\
Soba-Wanka Pyrochlore Coltan & 4.79 on the average & & \\
\hline
\end{tabular}

Sources : Thomas, Asuke and Yaro, 2014; Ministry of Mines and Steel Development (2012); Wills and Napier-Mum, (2006)

From Berry and Bruce (1966) using Bond's law in Yaro and Thomas (2009), the work index of an ore can be determined by comparing its grindability. Hence, the needs to determine the energy required in grinding an ore from the run-off mines to its liberation size prior to process to prevent over grinding or under grinding and to enhance the selection of appropriate grinding equipment cannot be overemphasized. In short, the textural relationship between minerals within the matrix of an ore and their relation to process selection requires the determination of their liberation sizes. This is the size to which an ore must be crushed or ground in order to produce separate particles of either valuable or gangue mineral that can be removed from the ore (as concentrate or tailings) with an acceptable efficiency by a commercial unit process .

The most widely used parameter to measure ore grindability is the Bond work index, Wi (Magdalimovic, 1989). Work index is the energy required in $\mathrm{kWh} / \mathrm{short}$-ton to reduce a given material from theoretically infinite size to $80 \%$ passing size, 100 microns (One Mine, 2010). The determination of work index using Bond's method can be compared to the method of determining it by Berry and Bruce (1966) known as the comparative method (Berry and Bruce, 1966). This method requires the use of reference ore of known grindability.

\section{Materials and Methods}

\subsection{Sample Collection}

The sample used in this research work was obtained from the main bulk at Enyigba Lead Ore deposit while the reference material (granite) was sourced from Anguwan-Boro granite deposit, Sabo, Kaduna metropolis using random sampling method. The samples were collected in lumps size at different locations by $30 \mathrm{~m}$ apart within the deposit.

\subsection{Sample Preparation}

The samples collected in lumps size were broken manually with sledge hammer to provide a required size acceptable to laboratory jaw crusher. The samples were crushed and pulverized, part of the pulverized sample were weighed for sieve analysis and part were weighed for ball mill for further size reduction (grinding).

\subsection{Procedure for the Determination of Work Index Using Modified Bond's Method}

The procedures were as follow;

1. $200 \mathrm{~g}$ each of ore samples under test and the reference ores were each crushed and pulverized.

2. An identical weight of test and reference ores were taken and sized by sieving into a number of size fractions using automatic sieve shaker for 10 minutes.

3. Each size fraction of the test and reference ores was weighed and the value noted as the "feed".

4. The "feed" test and reference ore were each gathered together and introduced into laboratory ball mill machine and ground for one hour.

5. The test and the reference ores from the laboratory ball mill machine were sized and each sieve fractions was weighed and the value noted as "product" or "discharge."

6. Sieve Size Analysis

The ground samples were sieved into the following sieve size fractions; $250 \mu \mathrm{m}, 180 \mu \mathrm{m}, 125 \mu \mathrm{m}, 90 \mu \mathrm{m}$ and $63 \mu \mathrm{m}$, these were arranged using root two $(\sqrt{2})$ method and were sieved for 10 minutes by automatic rotap sieve shaker. 


\section{Results and Discussions}

Table 2. Result of sieve size analysis of the "feed" reference material (Granite)

\begin{tabular}{|c|c|c|c|c|c|}
\hline $\begin{array}{c}\text { Sieve size } \\
\text { Range } \\
(\mu \mathrm{m})\end{array}$ & $\begin{array}{l}\text { Weight retained } \\
(\mathrm{g})\end{array}$ & $\%$ weight retained & Nominal aperture & $\begin{array}{l}\text { Cumulative \% } \\
\text { Weight retained }\end{array}$ & $\begin{array}{l}\text { Cumulative \% } \\
\text { Weight passing }\end{array}$ \\
\hline+250 & 31.48 & 15.74 & 250 & 15.74 & 84.26 \\
\hline$-250+180$ & 36.52 & 18.26 & 180 & 34.00 & 66.00 \\
\hline$-180+125$ & 44.06 & 22.03 & 125 & 56.03 & 43.97 \\
\hline$-125+90$ & 36.80 & 18.40 & 90 & 74.43 & 25.57 \\
\hline$-90+63$ & 23.54 & 11.77 & 63 & 86.20 & 13.80 \\
\hline-63 & 27.60 & 13.80 & - & 100 & 0.00 \\
\hline \multicolumn{6}{|c|}{ If $180 \mu \mathrm{m} \longrightarrow 66.00 \%$} \\
\hline & & $\mathrm{X} \mu \mathrm{m}$ & $\longrightarrow 80 \%$ & & \\
\hline \multicolumn{6}{|c|}{$\mathrm{X} \mu \mathrm{m}=180 \times 80=218.2 \mu \mathrm{m}$ at $80 \%$} \\
\hline
\end{tabular}

Table 3. Result of sieve size analysis of the product reference material (Granite)

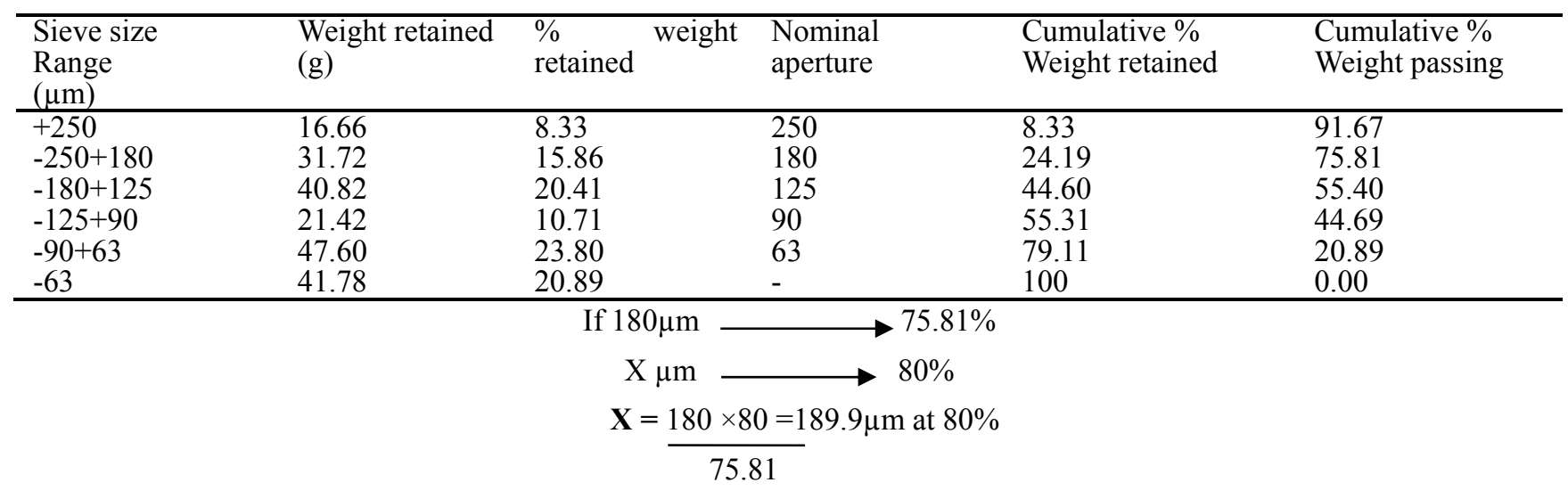

Table 4. Result of sieve size analysis of the feed test material (Lead)

\begin{tabular}{|c|c|c|c|c|c|c|}
\hline $\begin{array}{l}\text { Sieve size } \\
\text { Range } \\
(\mu \mathrm{m})\end{array}$ & $\begin{array}{l}\text { Weight } \\
\text { retained } \\
(\mathrm{g})\end{array}$ & $\begin{array}{l}\% \\
\text { retained }\end{array}$ & weight & $\begin{array}{l}\text { Nominal } \\
\text { aperture }\end{array}$ & $\begin{array}{l}\text { Cumulative \% } \\
\text { Weight retained }\end{array}$ & $\begin{array}{l}\text { Cumulative \% } \\
\text { Weight passing }\end{array}$ \\
\hline+250 & 32.16 & 16.08 & & 250 & 16.08 & 83.92 \\
\hline$-250+180$ & 36.08 & 18.04 & & 180 & 34.12 & 65.88 \\
\hline$-180+125$ & 38.16 & 19.08 & & 125 & 53.20 & 46.80 \\
\hline$-125+90$ & 32.58 & 16.29 & & 90 & 69.49 & 30.51 \\
\hline$-90+63$ & 45.54 & 22.77 & & 63 & 92.26 & 7.74 \\
\hline-63 & 15.48 & 7.74 & & - & 100 & 0.00 \\
\hline \multicolumn{7}{|c|}{ If $180 \mu \mathrm{m} \longrightarrow 65.88$} \\
\hline \multicolumn{7}{|c|}{$\mathbf{X} \mu \mathrm{m} \longrightarrow \quad 80 \%$} \\
\hline \multicolumn{7}{|c|}{$\mathbf{X}=180 \times 80=218.6 \mu \mathrm{m}$ at $80 \%$} \\
\hline
\end{tabular}

Table 5. Result of sieve size analysis of the "product" test material (Lead)

\begin{tabular}{llllll}
\hline $\begin{array}{l}\text { Sieve size } \\
\text { Range } \\
(\mu \mathrm{m})\end{array}$ & $\begin{array}{l}\text { Weight retained } \\
(\mathrm{g})\end{array}$ & $\begin{array}{l}\% \text { weight } \\
\text { retained }\end{array}$ & $\begin{array}{l}\text { Nominal } \\
\text { aperture }\end{array}$ & $\begin{array}{l}\text { Cumulative \% } \\
\text { Weight retained }\end{array}$ & $\begin{array}{l}\text { Cumulative \% } \\
\text { Weight passing }\end{array}$ \\
\hline+250 & 27.26 & 13.63 & 250 & 13.63 & 86.37 \\
$-250+180$ & 20.18 & 10.09 & 180 & 23.72 & 76.28 \\
$-180+125$ & 35.26 & 17.63 & 125 & 41.35 & 58.65 \\
$-125+90$ & 31.68 & 15.84 & 90 & 57.19 & 42.81 \\
$-90+63$ & 34.64 & 17.32 & 63 & 74.51 & 25.49 \\
-63 & 50.98 & 25.49 & - & 100 & 0.00 \\
\hline
\end{tabular}




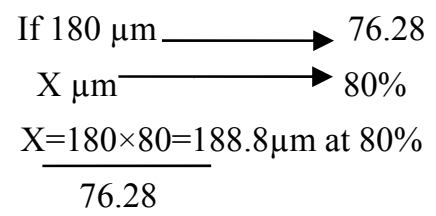

\section{Calculations of Result}

Using Bond's law, the work index of an ore can be determined by comparing its grindability:

Thus, If $r$ is the reference ore and $t$ is the ore under test. From bond's equation:

Then;

Therefore

$$
\mathrm{W}=\mathrm{W}_{\mathrm{t}}=\mathrm{W}_{\mathrm{ir}}\left(\begin{array}{cc}
\underline{10}- & \underline{10} \\
\sqrt{\mathrm{Pr}} & \sqrt{\mathrm{Fr} r}
\end{array}\right)=\mathrm{W}_{\mathrm{it}}\left(\begin{array}{cc}
\underline{10} & -\underline{10} \\
\sqrt{\mathrm{Pt}} & \sqrt{\mathrm{Ft}}
\end{array}\right)
$$

Where;

$$
\mathrm{W}_{\mathrm{it}}=\mathrm{W}_{\mathrm{ir}}\left(\begin{array}{cc}
\underline{10}-\underline{10} \\
\sqrt{\mathrm{F}_{\mathrm{r}}} & \sqrt{\mathrm{Pr}}
\end{array}\right) / \mathrm{W}_{\mathrm{it}}\left(\begin{array}{ll}
\underline{10} & -\underline{10} \\
\sqrt{\mathrm{P}_{\mathrm{t}}} & \sqrt{\mathrm{F}_{\mathrm{t}}}
\end{array}\right)
$$

$\mathrm{W}_{\mathrm{ir}}=$ work index of the reference ore

$\mathrm{W}_{\mathrm{it}}=$ work index of the test ore

$\mathrm{P}_{\mathrm{r}}=$ the diameter of the reference ore through

which $80 \%$ of the product passing $100 \mu \mathrm{m}$

$\mathrm{P}_{\mathrm{t}}=$ he diameter of the test ore through

which $80 \%$ of the product passing $100 \mu \mathrm{m}$

$\mathrm{F}_{\mathrm{r}}=$ the diameter of the reference ore through

which $80 \%$ of the feed passing $100 \mu \mathrm{m}$

$\mathrm{F}_{\mathrm{t}}=$ the diameter of the test ore through

which $80 \%$ of the feed passing $100 \mu \mathrm{m}$

$\mathrm{W}_{\mathrm{r}}=$ work input in kilowatt hour per short ton for the reference ore

$\mathrm{W}_{\mathrm{t}}=$ work input in kilowatt hour per short ton for the test ore.

$$
\begin{aligned}
& \mathrm{F}_{\mathrm{t}}=218.6 \\
& \mathrm{P}_{\mathrm{t}}=188.9 \\
& \mathrm{~F}_{\mathrm{r}}=218.2 \\
& \mathrm{P}_{\mathrm{r}}=189.9
\end{aligned}
$$

$\mathrm{W}_{\text {it }}=\mathrm{W}_{\text {ir }}$

Therefore

$$
\left(\begin{array}{ll}
\frac{10}{\sqrt{P_{\mathrm{r}}}}-\frac{10}{\sqrt{\mathrm{Fr}}}
\end{array}\right) / \mathrm{W}_{\text {it }}\left(\begin{array}{ll}
\frac{10}{\sqrt[10]{10}} & \frac{\sqrt{\mathrm{P}_{\mathrm{t}}}}{\sqrt{\mathrm{F}_{\mathrm{t}}}}
\end{array}\right)
$$

$\mathrm{W}_{\mathrm{it}}=15.13 \quad\left(\frac{10}{\sqrt{189.9}}-\frac{10}{\sqrt{ } 218.2}\right) / \quad\left(\frac{10}{\sqrt{ } 188.8}-\frac{10}{\sqrt{ } 218.6}\right)$ 


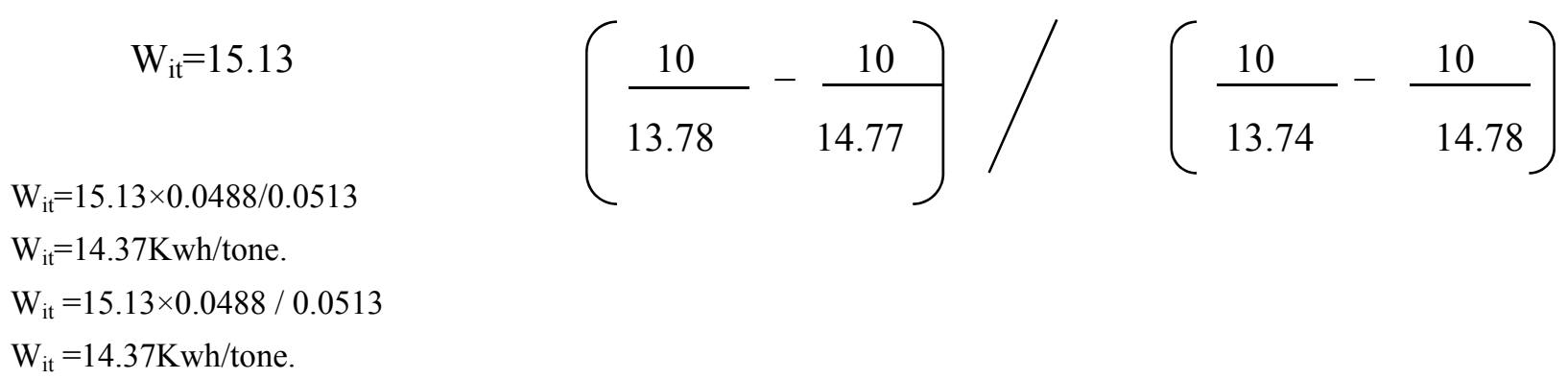

\section{Discussions of Results}

From the result of the experiment performed on Enyigba Lead Ore, Ebony State using modified Bond' Energy method, the $80 \%$ passing was obtained to be $218.2 \mu \mathrm{m}$ and $189.9 \mu \mathrm{m}$ for the reference material (Feed \& Product) as shown in table 2 and 3 and $218.6 \mu \mathrm{m}, 188.8 \mu \mathrm{m}$ for the test ore (Feed \& Product) as shown in table 4 and 5 respectively.

The work index of Enyigba Lead Ore, Ebony State was calculated to be $14.37 \mathrm{kwh} /$ short ton, this is within the limit of the previous research on lead work index (Weiss, 1965).

\section{Conclusions and Recommendatons}

\subsection{Conclusion}

The determination of work index of Enyigba Lead Ore was investigated using modified Bond's Energy method. From the results of the experiments the work index was found to be $14.37 \mathrm{kwh} / \mathrm{ton}$, this means that, it will cost \#395.18 (when taking \#27.50 being a unit cost of power consumption in Nigeria), to comminute one tone of Enyigba Lead Ore to $80 \%$ passing 100 microns.

This parameter is significant and therefore it is expected that this energy requirement (14.37kWh/tone) will aid in the design of the grinding circuit for beneficiation plant for the Enyigba lead-Zinc ore.

\subsection{Recommendation}

The exploitation of Enyigba Lead Ore is therefore recommended for industries and foreign investors, having established the energy require to successfully attain a maximum grindability without under- over-grinding the ore.

\section{References}

Anon, (2014); www.ime.co.uk/zinc-industryusage.asp

Bate, R. I. (1988). Industrial Rock and Mineral. Journal of Industrial Mineral, 24, 15.

Benkhelil, J. (1986). Structure et Evolution g6odynamique du bassin intracontinental de la B6nou6 (Nig/ ria).These de Doctorat d tat, Nice. 231.

Benkhelil, J. (1982). Benue Trough and Benue Chain. Geol. Mag., I19, 155-168. http://dx.doi.org/10.1017/S001675680002584X

Berry, T. F., \& Bruce, R. W. (1966). A simple method of determine the grind-ability of ores. Canadian Mining Journal, 63.

Berry, T. F., \& Bruce, R. W. (1966). A Simple Method of Determining the Grindability of Ores. Canadian Mining Journal, 87, 63-65.

Bond, F. C. (1952). The Third Law of Comminution. Transaction on AIME Mining Engineering, 193(1952), 193-484. Books, Amsterdam.

Etim, O. N., Louis, P., \& Maurin, J. C. (1998). Interpretatlon of electrical soundings on the Abakaliki

Farington, J. L. (1952). A preliminary description of the Nigerian lead-zinc field. Econonic Geology, 47, 583-608. http://dx.doi.org/10.2113/gsecongeo.47.6.583

Geological Survey of Nigeria (1980). The geology of part of South Western Nigeria Bulletin, 31(26), 1-40.

Grant, N. K. (1971). A compilation of radiometric ages from Nigeria. J. Min. Geol., 6, 37-55.

Large, D. E. (1983). Sediment-hosted massive sulphide lead-zinc deposits: An empirical model, in Sangster, D.F., ed., Sediment-hosted stratiform lead-zinc deposits: Mineralogical Association of Canada, Short Course Handbook 8, p. 1-29. lead-zlnc and brine prospects. SW Nigeria: geological and genetic implications. J. Afr. EarthScL, 7(5/6), 743-747. 
Lydon, J. W. ( 2007). An overview of the economic and geological contexts of Canada's major mineral deposit types. In Goodfellow, W.D., ed., Mineral Deposits of Canada: A Synthesis of Major Deposit-Types, District Metallogeny, the Evolution of Geological Provinces, and Exploration Methods: Geological Association of Canada, Mineral Deposits Division, Special Publication, 5, 3-48.

Mackay, R. A. (1946). A comparative study of two lead-zinc occurrences in Plateau and OgoJa Provinces. Ann.Rept. Geol. Surv. Nigeria.

Magdalimovic, N. M. (1989). Calculation of Energy Required for Grinding in a Ball Mill. Journal of Mineral Processing, 25, 41-42. http://dx.doi.org/10.1016/0301-7516(89)90055-0

Magdalimovic, N. M. (1989). Calculation for Energy required for grinding in ball mill. International Journal of Mineral Processing 25, 41. http://dx.doi.org/10.1016/0301-7516(89)90055-0

Maurin, J. C. (1986). Analyse de zones d6crochantes dans le foss6 de la Benou6 (Nig6ria) et syst matiques U-Pb et $\mathrm{Pb}-\mathrm{Pb}$ appliqu6es aux mineralisations uraniferes et $\mathrm{Pb}-\mathrm{Zn}$ associ es. These de Doctorat, Montpellier, 11, 211.

Maurin, J. C., \& Lancelot, J. R. (1987). Origine des min rallsatlons de Pb-Zn de la Vall $\sim$ 'e de La Benou (Nig6rla) d'apr $\sim$ S Lamurde Anticline composition en $\mathrm{Pb}$ des gal nes et de rencaissant. Mineral Depostta, 22, 99-108. http://dx.doi.org/10.1007/BF00204686

Ministry of Mines and Steel Development (2012). Road Map for the Development of Solid Minerals and Metals Sector.Stack Holders Forum, Abuja, 3, 4-9.

Napier-Munn, T. J., Morell, S., Morrison, R. D., \& Kojovic, T. (1996). Mineral Comminution Circuits. Their Operation and Optimisation. JKMRC Monograph Series in Mining and Mineral Processing 2, University of Queensland, Australia.

Nwachukwu, S. O. (1974). Temperatures of formation of the southern portion of the Benue Trough, Nigeria. J. Min. GeoL., 11, 45-55.

Offodfle, M. E., \& Reyment, R. A. (1976). Stratigraphy of the Keana-Awe area of the Middle Benue region of Nigeria. BulL Geol. Inst. Univ. Uppsala, 7, 37-66.

Olade, M., \& Morton, R. D. (1985). Origin of lead-zinc mineralization in the southern Benue trough, Nigeria. Fluid inclusions and trace element studies. MineraL Depostta, 20, 76-80. http://dx.doi.org/10.1007/bf00204313

Olade, M. A. (1976). On the genesis of lead-zinc deposits of Nigeria's Benue Rift (Aulacogen) : a reinterpretation. $J$. Mtn. Geo/., 13, 20-27.

Oladunni, O. A., Shehu, A. Y., Dungka, G. T., Asuke, F., \& Dauda, E. T. (2015). Determination of Work Index of Gyel-Bukuru Columbite Ore in Plateau State, Nigeria. Journal of Minerals and Materials Characterization and Engineering, 3, 194-203, Published Online May 2015 in SciRes

One Mine (2010). Summary and Determination of the Bond Work Index Using an Ordinary Laboratory Batch Ball Mill. http://www.onemine.org/search/summary.cmf

Taylor, S. R., \& McLennan, S. M. (1995). The geochemical evolution of the continental crust. Rev. Geophys., 33, 241-265. http://dx.doi.org/10.1029/95RG00262

Thomas, D. G., Asuke, F., \& Yaro, S. A. (2014). Determination of Some Conceptual Mineral Processing Parameters of Soba-Wanka Pyrochlore-Col Tan Mineral Ore Deposit. 2014 Nigeria Engineering Conference, 2, 32-41.

Weiss, N. L. (1985). S.M.E Mineral Processing Handbook by American Institute of Mining, Metallurgical \& Petroleum Engineering, Incorporated. Kingsport, New York. 2.

Whittles, D. N., Kingman, S. W., \& Reddish, D. J. (2003). Application of numerical modelling for prediction of the influence of power density on microwave-assisted breakage. International Journal of Mineral Processing, Elsevier, 68, 71-91, 2003. http://dx.doi.org/10.1016/s0301-7516(02)00049-2

Wills, B. A., \& Napier-Munn, T. Y. (2006). Wills Mineral Processing Technology. An introduction to the practical aspects of ores treatment and mineral recovery, 108-115.

Wills, B. A., \& Napier-Mum, T. J. (2006). Mineral Processing Technology. 7th Edition, Elsevier Science \& Technology

\section{$(\mathrm{cc}) \mathrm{BY}$}

This work is licensed under a Creative Commons Attribution 3.0 License. 